Far Eastern Entomologist

\begin{tabular}{lll}
\hline Number 414: 16-24 & ISSN 1026-051X (print edition) & September 2020 \\
\hline
\end{tabular}

https://doi.org/10.25221/fee.414.3

http://zoobank.org/References/CE1A02FE-2F85-4AC7-B59D-1C9E8FDC8F57

\title{
TO THE KNOWLEDGE OF THE GENUS COLORADOA WILSON, 1910 (HEMIPTERA: APHIDIDAE)
}

\author{
R. Kh. Kadyrbekov \\ Institute of Zoology, Ministry of Education and Sciences of Kazakhstan Republic, \\ Academgorodok, Al-Farabi av., 93, Almaty, 050060, Kazakhstan. \\ E-mail:rustem_aijan@mail.ru; rustem.kadyrbekov@zool.kz
}

Summary. Coloradoa ajaniae Kadyrbekov sp. n. from host plant Ajania fastigiata (C. Winkl.) Poljak. is described from Kazakhstan. New species is similar to C. mesasiatica Kadyrbekov, 2004 but differs from latter by ratio of setae on 8th tergite to the diameter of 3 rd antennomere near base (1.0-1.3 vs 0.8-1.0), by ratio of terminal processes to width of the head between eyes (0.27-0.36 and 0.33-0.55, respectively), by number of setae on 8th abdominal tergite (6-8 vs 8-10), and by host plant genus (Ajania vs Artemisia). New synonymy are proposed: Coloradoa brevipilosa (Ivanovskaja, 1958) $=$ Coloradoa huculaki Szelegiewicz, 1981, syn. n., Coloradoa viridis (Nevsky, 1929) = Coloradoa nodulosa Zhang et Zhong, 1980, syn. n. A key to species of genus Coloradoa Wilson, 1910 is compiled. key.

Key words: aphids, Aphididae, Macrosiphini, taxonomy, new species, new synonymy,

Р. Х. Кадырбеков. К познанию рода Coloradoa Wilson, 1910 (Hemiptera: Aphididae) // Дальневосточный энтомолог. 2020. N 414. С. 16-24.

Резюме. Из Казахстана описан новый вид Coloradoa ajaniae Kadyrbekov sp. n. (кормовое растение - Ajania fastigiata (C. Winkl.) Poljak). Новый вид близок к C. mesasiatica Kadyrbekov, 2004, но отличается от него отношением длины щетинок на 8-м тергите брюшка к диаметру третьего членика усиков в основании (1.0-1.3 против 0.8-1.0), шпица к ширине головы между глазами $(0.27-0.36$ в сравнении с $0.33-0.55)$, количеством щетинок на 8-м тергите брюшка (6-8 и 8-10), растением-хозяином из другого рода. Установлена новая синонимия: Coloradoa brevipilosa (Ivanovskaja, 1958) = Coloradoa huculaki Szelegiewicz, 1981, syn. n., Coloradoa viridis $($ Nevsky, 1929) $=$ Coloradoa nodulosa Zhang et Zhong, 1980, syn. n. Составлена определительная таблица видов рода Coloradoa Wilson, 1910.

\section{INTRODUCTION}

Coloradoa Wilson, 1910 is a large aphid genus with 31 species in the world fauna (Remaudiere \& Remaudiere, 1997; Blackman \& Eastop, 2006; Favret, 2019). The species of the genus are Palaearctic, except $C$. rufomaculata (Wilson, 1910) widely distributed around the world. Trophically, they are associated with wormwood (Artemisia) and several similar genera of Asteraceae. All known species live on the aerial parts of fodder plants and are monophagous or limited oligophagous, again except polyphagous C. rufomaculata. 
A new species of Coloradoa was collected in the Dzungarian Alatau Mountains on Ajania fastigiata (Asteraceae) - a new host plant for this genus. Holotype and paratypes are deposited in the collection of the Institute of Zoology, Ministry of Education and Sciences of Kazakhstan Republic (Almaty).

The following abbreviations are used in the text: BL - body length; ANT - antennae length; ANT III - third antennal segment; ANT IV - forth antennal segment; ANT V - fifth antennal segment; ANT VI - sixth antennal segment; ANT VIb - base of sixth antennal segment; ANT IIIBD - basal diameter of 3rd antennal segment; PT - processus terminalis; HW - width of head between eyes; URS - apical rostral segment; HFEM - hind femora; HTIB - hind tibiae; HT II - second segment of hind tarsus; ABD TERG III - 3rd abdominal tergite; ABD TERG VIII - 8th abdominal tergite; SIPH - siphunculi length.

All measurements (in millimeters), number of setae, rhinariae, indexes are given by extreme variants and arithmetical means.

\section{TAXONOMY}

Coloradoa ajaniae Kadyrbekov, sp. n.

http://zoobank.org/NomenclaturalActs/F56641E8-F976-46B9-909D-755BF169399E

Figs $1-5$

TYPE MATERIAL. Holotype: apterous viviparous female, slide No 5430, Kazakhstan: Almaty region, Dzhungarian Alatau Mts, Sarkan River canyon, $32 \mathrm{~km}$ SE of Sarkan town, h 1400 m, 4. IX 2015, leg. R. Kadyrbekov. Paratypes: 18 apterous viviparous females together with holotype.

DESCRIPTION. Apterous viviparous female (19 specimens). Body is elliptical, 1.20 1.52 (Fig. 1). Frons is slightly convex, without median and antennal tubercles, with stickformed broadened on the apex setae $(0.017-0.023)$, which are $0.7-1.0$ of basal diameter of $3 \mathrm{rd}$ antennal segment (fig. $1 \mathrm{~b}$ ). Width of head between eyes $0.51-0.58$. Antennae are sixsegmented, $0.52-0.74$ of body length. Third antennal segment is $1.30-1.67$ of 4 th one, 0.75 1.00 of the processus terminalis and $0.50-0.65$ of the 6th segment, $0.11-0.15$ of the body length, $0.90-1.24$ of the siphunculi length. Forth antennal segment is $0.62-0.78$ of the $3 \mathrm{rd}$ antennal segment. Fifth antennal segment is $0.83-1.08$ of the base of 6th segment. Processus terminalis is $1.5-1.9$ of the base of 6th segment, $1.00-1.25$ of the 3rd antennal segment, 0.27 0.36 of the width of head between eyes, with 3 apical setae. Base of 6th segment is $0.57-0.76$ of the 3rd antennal segment. Secondary rhinaria are absent. Setae on the 3rd antennal segment $(0.010-0.012)$ are short stick-formed, $0.4-0.5$ of its basal diameter. Clypeus is normal, rostrum reaches the base of hind coxae. Its apical rostral segment (Fig. 2) is slender, stiletto-formed, $1.0-1.1$ of the 2 nd segment of hind tarsus, $0.40-0.65$ of the length of 3rd antennal segment, $0.65-1.00$ of the base of 6th antennal segment, $0.16-0.18$ of the width of head between eyes, $0.47-0.64$ of the siphunculi length, with 6 accessory setae. There are 6 setae on the penultimate segment. Dorsal setae on 3rd and 8th abdominal tergites are spatula-formed, $(0.025-0.032)$ $1.1-1.2$ and (0.023-0.029) $1.0-1.3$ of basal diameter of the 3rd antennal segment (Fig. 4). 8th tergite with 6-8 setae. Siphunculi are swollen in the apical part with distinct rims, they are $0.11-0.15$ of the body length, $1.35-1.65$ of the cauda, $1.55-2.20$ of the apical rostral segment, $1.75-2.20$ of the 2 nd segment of hind tarsus, 1.3-1.7 of the base of 6th segment, $0.27-0.36$ of the width of head between eyes (Fig. 3). Cauda is triangular conic, $0.071-0.093$ of the body length, 1.1-1.2 of its basal width, with 5-6 setae (Fig. 5). Genital plate is oval, with $2-4$ setae on disc and $8-12$ ones along its posterior margin. Legs are normally developed. Hind femora are $0.28-0.29$ of the body length, $0.69-0.76$ of the width of head between eyes. 
Hind tibiae are $0.46-0.48$ of the body length, $1.09-1.21$ of the width of head between eyes. Second segment of hind tarsus is $0.62-0.90$ of the base of 6 th antennal segment. Setae on the femora and tibiae are stick-formed with slightly broadened apices. First tarsal segment with $3: 3: 2$ setae.

COLOR IN THE LIFE. Aphids are light-greenish with red eyes.

COLOR ON SLIDE. Body is pale, only apical and penultimate rostral segments, 4-6th antennal segments, clypeus, apices of the tibiae and tarsi, apices of siphunculi, cauda, anal and genital plates are darkened.

MEASUREMENTS (holotype). Body 1.28; antennae: 0.74-0.75: III 0.16, IV 0.10-0.12, V 0.10 , VI $0.28(0.10+0.18)$; siphunculi 0.15 ; cauda 0.11 ; apical rostral segment 0.092 ; second segment of hind tarsus 0.081 .

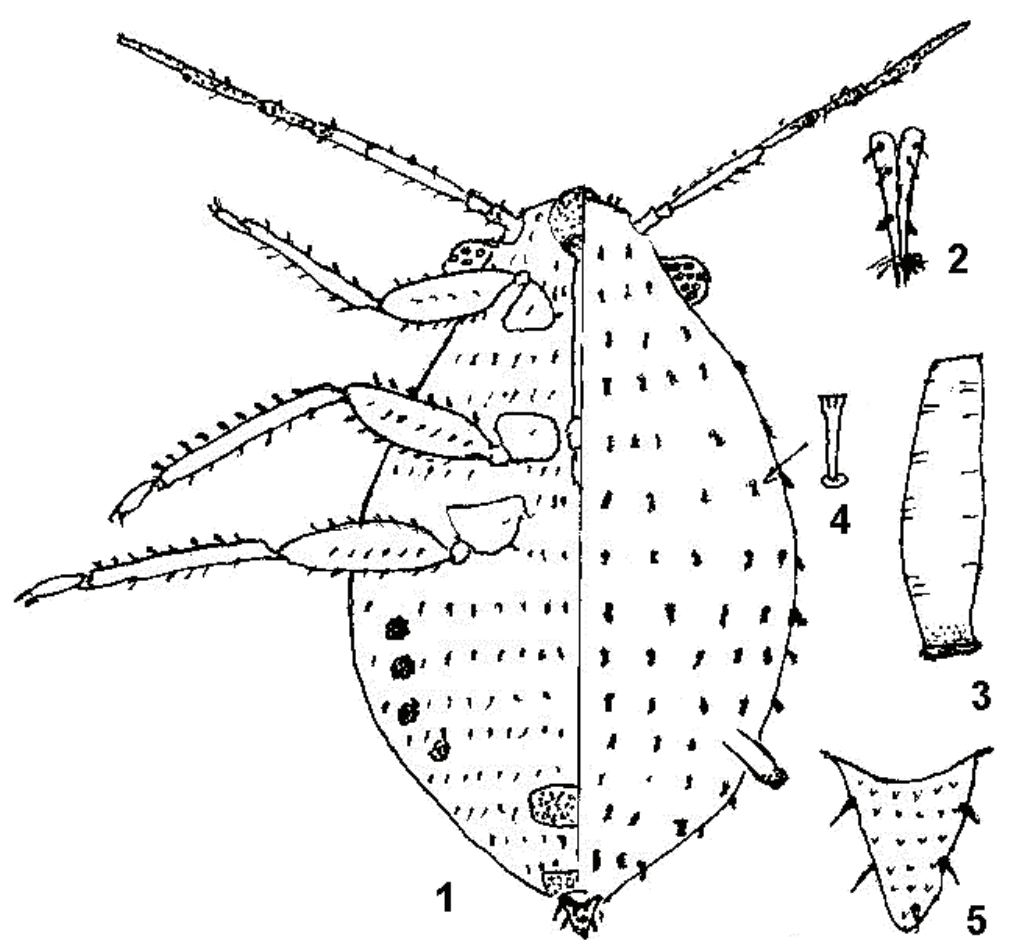

Figs 1-5. Coloradoa ajaniae sp. n., apterous viviparous female: 1 - body; 2 - ultimate rostral segment; 3 - siphunculus; 4 - dorsal seta; 5 - cauda.

MEASUREMENTS AND RATIONS OF BODY PARTS (apterous viviparous females). Measurements: $\mathrm{BL}=1.20-1.52 ;$ ANT $=0.65-1.01 ;$ ANT III $=0.14-0.22 ;$ ANT IV $=0.09$ 0.16 ; ANT V $=0.09-0.15 ;$ ANT VIb $=0.09-0.13$; ANT IIIBD $=0.019-0.023 ;$ PT $=0.14$ 0.23 ; longest seta on ANT III $=0.010-0.012$; length of longest seta on ANT VI $b=0.006$ 0.008 ; length of longest frontal seta $=0.017-0.023 ; \mathrm{HW}=0.51-0.58$; URS $=0.081-0.100$; width of URS $=0.046-0.058 ;$ HFEM $=0.35-0.44 ;$ HTIB $=0.56-0.70$; HT II $=0.08-0.10$; longest seta on ABD TERG III $=0.025-0.032$; longest seta on $\mathrm{ABD}$ TERG VIII $=0.023$ 0.029 ; $\mathrm{SIPH}=0.14-0.21$; cauda $=0.09-0.13$; basal width of cauda $=0.104-0.115$. Ratios: 
$\mathrm{ANT} / \mathrm{BL}=0.52-0.74 ; \mathrm{PT} / \mathrm{ANT}$ VI $\mathrm{b}=1.5-1.9 ; \mathrm{PT} / \mathrm{ANT} \mathrm{III}=1.00-1.25 ; \mathrm{PT} / \mathrm{HW}=0.27$ 0.36 ; $\mathrm{ANT}$ III $/ \mathrm{BL}=0.11-0.15 ;$ ANT III/SIPH $=0.90-1.24 ;$ ANT III $/ \mathrm{ANT}$ IV $=1.30-1.67$; ANT III/ANT VI $=0.50-0.65 ;$ ANT III/PT $=0.75-1.00 ;$ ANT IV/ANT III $=0.62-0.78 ;$ ANT $\mathrm{V} / \mathrm{ANT} \mathrm{VIb}=0.83-1.08$; ANT VIb/ANT III $=0.57-0.76$; longest seta on ANT III $/$ ANT III $\mathrm{BD}=0.4-0.5$; cephalic frontal seta/ANT III $\mathrm{BD}=0.7-1.0 ; \mathrm{URS} /$ its basal width $=2.0-2.5$; URS/ANT VI $b=0.65-1.00 ;$ URS/HW $=0.16-0.18$; URS/HT II $=1.0-1.1 ; \mathrm{URS} / \mathrm{SIPH}=$ $0.47-0.64 ; \mathrm{HFEM} / \mathrm{BL}=0.28-0.29 ; \mathrm{HFEM} / \mathrm{HW}=0.69-0.76 ; \mathrm{HTIB} / \mathrm{BL}=0.46-0.48 ;$ $\mathrm{HTIB} / \mathrm{HW}=1.09-1.21 ; \mathrm{H}$ II/ANT VI $\mathrm{b}=0.62-0.90$; longest seta on ABD TERG III/ANT III bd $=1.1-1.2$; longest seta on ABD TERG VIII/ ANT III bd $=1.0-1.3 ; \mathrm{SIPH} / \mathrm{BL}=0.11-$ $0.15 ; \mathrm{SIPH} / \mathrm{HW}=0.27-0.36 ; \mathrm{SIPH} / \mathrm{cauda}=1.35-1.65 ; \mathrm{SIPH} / \mathrm{ANT}$ VI $\mathrm{b}=1.3-1.7 ; \mathrm{SIPH} /$ $\mathrm{URS}=1.55-2.20 ; \mathrm{SIPH} / \mathrm{HT}$ II $=1.75-2.20 ;$ cauda/its basal width $=1.1-1.2 ;$ cauda/BL $=$ $0.071-0.093$.

HOST PLANT. Ajania fastigiata (C. Winkl.) Poljak. (Asteraceae). Aphids suck on the upper side of leafs.

DIAGNOSIS. Coloradoa ajaniae sp. n. similar to C. mesasiatica Kadyrbekov, 2004, but differs from latter by the ratios of setae on 8th tergites to diameters of third antennal segment in base (1.0-1.3 vs $0.8-1.0)$, processus terminalis to width of head between eyes $(0.27-0.36$ in comparison to $0.33-0.55)$, number of setae on 8th tergite (6-8 vs 8-10) and host plant from another genus.

DISTRIBUTION. Kazakhstan.

ETYMOLOGY. Species is named after the generic name of host plant.

\section{Coloradoa brevipilosa (Ivanovskaja, 1958)}

Coloradoa brevipilosa (Ivanovskaja, 1958): 129-130 (holotype: apterous viviparous female, Russia: Slavgorod; in the collection of Institute of Systematic and Ecology of Animals, Siberian Branch, Russian Academy of Sciences, Novosibirsk.

Coloradoa huculaki Szelegiewicz, 1981: 84-85 (holotype: apterous viviparous female, Hungary: Hortobagy, Ujiszentmargita; in the collection of the Institute of Zoology, Polish Academy of Sciences, Warszawa), syn. $\mathbf{n}$.

NOTES. These two species cannot be distinguished by the morphological characteristics available in the descriptions (Table 1). Thus, Coloradoa huculaki is the junior synonym of $C$. brevipilosa.

Table 1. Ratios of the body parts of apterous viviparous females of Coloradoa brevipilosa and C. huculaki.

\begin{tabular}{l|c|l|l|l|l|l|c}
\hline \multirow{2}{*}{ Species } & \multicolumn{7}{|c}{ Ratios of morphological characters } \\
\cline { 2 - 8 } & $\begin{array}{l}\text { ANT/ } \\
\text { BL }\end{array}$ & $\begin{array}{l}\text { ANT3/ } \\
\text { ANT4 }\end{array}$ & $\begin{array}{l}\text { ANT3/ } \\
\text { ANT 6 }\end{array}$ & $\begin{array}{l}\text { ANT3/ } \\
\text { PT }\end{array}$ & $\begin{array}{l}\text { PT/ } \\
\text { ANT 6b }\end{array}$ & $\begin{array}{l}\text { SIPH/ } \\
\text { BL }\end{array}$ & $\begin{array}{l}\text { SIPH/ } \\
\text { CAUDA }\end{array}$ \\
\hline C. brevipilosa & 0.58 & 1.44 & 0.62 & 0.96 & 1.85 & 0.21 & 3.45 \\
\hline C. huculaki & $0.6-0.8$ & $1.25-1.66$ & $0.54-0.66$ & $0.8-1.0$ & $1.6-2.4$ & 0.23 & $2.3-4.2$ \\
\hline
\end{tabular}

Coloradoa viridis (Nevsky, 1929)

Neaphis viridis Nevsky, 1929: 212-214 (holotype: apterous viviparous female, Uzbekistan: Tashkent, Fergana, in the collection of Zoological Institute RAN, St. Petersburg).

Coloradoa nodulosa Zhang et Zhong, 1980: 56-57 (holotype: apterous viviparous female, China: Bejing, in the collection of Institute of Zoology, Academia Sinica, Bejing), syn. $\mathbf{n}$. 
NOTES. It is impossible to distinguish Coloradoa nodulosa from C. viridis according to the morphological characteristics available in the descriptions, because the measurement data are included in the amplitude of variability of these characters (Table 2). Both taxa live on the same plant (Artemisia annua). Thus, $C$. nodulosa is considered here as a junior synonym of $C$. viridis.

Table 2. Ratios of the body parts of apterous viviparous females of Coloradoa viridis and $C$. nodulosa.

\begin{tabular}{l|c|c|c|c|l|l|c}
\hline \multirow{3}{*}{ Species } & \multicolumn{7}{|c}{ Ratios of morphological characters } \\
\cline { 2 - 9 } & $\begin{array}{l}\text { ANT/ } \\
\text { BL }\end{array}$ & $\begin{array}{l}\text { ANT3/ } \\
\text { ANT4 }\end{array}$ & $\begin{array}{l}\text { ANT3/ } \\
\text { ANT 6 }\end{array}$ & $\begin{array}{l}\text { ANT3/ } \\
\text { PT }\end{array}$ & $\begin{array}{l}\text { PT/ } \\
\text { ANT 6b }\end{array}$ & $\begin{array}{l}\text { SIPH/ } \\
\text { BL }\end{array}$ & $\begin{array}{l}\text { SIPH/ } \\
\text { CAUDA }\end{array}$ \\
\hline C. viridis & 0.51 & $2.4-2.5$ & 0.96 & 1.5 & $1.55-1.80$ & $0.20-0.21$ & $2.2-3.0$ \\
\hline C. nodulosa & 0.53 & 2.38 & 1.05 & 1.81 & 1.38 & 0.18 & 2.33 \\
\hline
\end{tabular}

Key to species of Coloradoa by apterous viviparous females

This key is based on a key to Western Palaearctic species (Kadyrbekov, 2004) and descriptions of all currently known species (Bozhko, 1953, 1976; Börner, 1939, 1940, 1952; Heie, 1991; Ivanovskaja, 1977; Hille Ris Lambers, 1948; Kadyrbekov, 2004; MamontovaSolukha, 1963; Nevsky, 1929; Ossiannilsson, 1959; Remaudiere \& Leclant, 1969; Shaposhnikov, 1964; Szelegiewicz, 1969; Takahashi, 1965; Verma, 1974, this paper) except the $C$. kashmirica Rishi et Lone, 1985 and C. kondoi Shinji, 1942.

1(38) Siphunculi are normally 1.4 or more times longer than the cauda, if they are only $1.1-$ 1.2 times longer (some specimens of $C$. inodorella), then the dorsal setae on the $3-5$ th abdominal tergites are no more than 0.6 times the diameter of the 3 rd segment antennae at the base, and siphunculi are 1.7-2.1 times of the length of the ultimate rostral segment.

2(7) The antennae of wingless and winged viviparous females are five-segmented.

3(4) Processus terminalis is $1.38-1.80$ times longer than base of last antennal segment. The siphunculi are 2.2-3.0 times longer than the cauda. On Artemisia annua, A. vulgaris. Azerbaijan, Pakistan, India, Central Asia, Kazakhstan (south), Mongolia, China

C. viridis (Nevsky, 1929)

4(3) Processus terminalis is not more than 1.2 times longer than the base of the last antennal segment. Siphunculi no more than 2 times of cauda.

5(6) Siphunculi are 0.16 body lengths and 1.8 times longer than the cauda. On Artemisia procera. Ukraine .................................................... C. procerae (Bozhko, 1953)

6(5) Siphunculi are 0.12 body lengths and 1.40-1.45 times longer than the cauda. Mesonotal fork with very short processes. On Artemisia pontica. Czech Republic, China

C. ponticae (Börner, 1940)

7(2) The antennae of wingless and winged viviparous females are six-segmented.

8(19) Siphunculi are normally no more than 0.16 body lengths, if they are $0.17-0.18$ (single specimens of C. achilleae, C. tanacetina), then the aphids lives on Achillea and Tanacetum.

9(10) Siphunculi are $0.10-0.12$ body lengths. The ultimate rostral segment is no more than 0.7 of the length of the 2nd segment of the hind tarsus. On Matricaria inodora. Northern and Central Europe, Russia (European part), Turkey

C. inodorella Ossiannilsson, 1959

10(9) Siphunculi are at least 0.12 of the body length, if 0.11 (some specimens of $C$. ajaniae), then the ultimate rostral segment is equal to or longer than the 2nd segment of the hind 
tarsus. The last segment of the proboscis is equal to at least 0.8 of the length of the 2 nd segment of the hind tarsus. Not on Matricaria inodora.

11(12) Siphunculi are very long, 2.2-4.2 times longer than the cauda and 2.6-3.3 times longer than the second segment of the hind tarsus. On Artemisia absinthium, A. ponticae, A. sieversiana. Hungary, Kazakhstan, Russia (Western Siberia), China

C. brevipilosa (Ivanovskaja, 1958)

12(11) Siphunculi not more than 2 times longer than the cauda and not more than 2.3 times the length of the 2 nd segment of the hind tarsus.

13(16) The ultimate rostral segment is $0.8-0.9$ the length of the 2 nd segment of the hind tarsus.

14(15) Processus terminalis 2.2-2.6 times longer than the base of 6-th antennal segment. Cauda with 6-7 setae. The 8-th tergite with 4 setae. On Artemisia absinthium. Europe, Kazakhstan, North America (introduced) ....

C. absinthii (Lichtenstein, 1885)

15(14) Processus terminalis is 1.3-1.8 times longer than base of 6-th antennal segment. Cauda with 5 setae. The 8-th tergite of abdomen with 8 setae. On Artemisia camphorata. France, Italy, Hungary

C. palmerae Börner, 1952

16(13) The ultimate rostral segment is at least 0.9 times the length of the 2 nd segment of the hind tarsus.

15(16) The ultimate rostral segment is $0.9-1.0$ the length of the 2 nd segment of the hind tarsus. The siphunculi are 1.8-2.0 times longer than the cauda. On Tanacetum vulgare. Europe, Kazakhstan, USA (introduced)

C. tanacetina (Walker, 1850)

16(15) The ultimate rostral segment is equal to or longer than the 2nd segment of the hind tarsus. Siphunculi are no more than 1.8 times longer than the cauda. Not on Tanacetum.

17(18) The dorsal setae of the 8th tergite of the abdomen are $0.8-1.0$ in diameter of the 3 rd antennal segment at the base. Processus terminalis is $0.33-0.55$ of the width of the head between the eyes. The 8-th tergite with 8-10 setae. On Artemisia sp., A. heptapotamica, A. transiliensis, Kazakhstan (southeast) .....

C. mesasiatica Kadyrbekov, 2004

18(17) The dorsal setae of the 8-th tergite of the abdomen are equal to 1.0-1.3 of the diameter of the $3 \mathrm{rd}$ antennal segment at the base. Processus terminalis is $0.27-0.36$ of the width of the head between the eyes. The 8-th tergite with 6-8 setae. On Ajania fastigiata. Kazakhstan (southeast)

C. ajaniae Kadyrbekov, sp. n.

19(8) Siphunculi are normally at least 0.18 body lengths, if less (single specimens of $C$. artemisiae, $C$. deserta, $C$. scopariae), then either the ultimate rostral segment is at least 1.2 times the length of the 2 nd segment of the hind tarsus, or 8-th tergite of the abdomen at least with 10 setae, or the processus terminalis is short, equal to $1.2-1.4$ of the base length of the last segment of the antennae.

20(23) The third segment of the antennae is not less than 2.1 times longer than the 4th and not less than 1.1 times longer than the length of the 6th antenna segment. On Santolina spp.

21(22) Processus terminalis is 1.1-1.3 times longer than base of 6th antennal segment. The ultimate rostral segment is $0.67-0.78$ the length of the 2 nd segment of the hind tarsus. Siphunculi are 1.85-2.14 times longer than 2nd segment of hind tarsus. On Santolina rosmarinifolia. Spain

C. moralesi Remaudiere et Leclant, 1969

22(21) Processus terminalis is 1.2-1.6 times longer than base of 6th antennal segment. The ultimate rostral segment is $1.25-1.50$ times the length of the 2nd segment of the hind tarsus. Siphunculi are 2.9-4.3 times longer than 2nd segment of hind tarsus. On Santolina chamaecyparissus. England, France, Spain, Italy, Israel, Lebanon, Iran

C. bournierii Remaudiere et Leclant, 1969

23(20) The third antennal segment is no more than 1.8 times longer than the 4th and is no more than 0.75 times the length of the 6th antennae. Not on Santolina spp. 
24(25) The setae on the body are long, on the forehead $1.4-1.7$, on the 8 th tergite of the abdomen 2.5-3.3 times the diameter of the third segment of the antennae at the base. The 8th tergite of the abdomen with 10-12 setae. On Artemisia santolina. China (Xinjiang) C. deserta Kadyrbekov, 2004

25(24) The setae on the body are noticeably shorter, on the forehead they are no more than 0.5 , on the 8 th tergite of the abdomen no more than 1.2 times the diameter of the 3 rd antennal segment at the base. The 8th tergite with no more than 5 setae.

26(29) The ultimate rostral segment is 1.2-1.5 times longer than the length of the 2nd segment of the hind tarsus. Siphunculi are semi-cylindrical, not swollen in the upper half.

27(28) Processus terminalis is only 1.2-1.4 times longer than base of 6th antennal segment. On Artemisia scoparia. Pakistan, Mongolia C. scopariae Szelegiewicz, 1969

28(27) Processus terminalis is 1.7-1.8 times longer than base of 6th antennal segment. On Artemisia vulgaris. Europe, Front Asia, India, Nepal, North America (introduced)

C. artemisiae (del Guercio, 1913)

29(26) The ultimate rostral segment is $1.0-1.3$ the length of the 2 nd segment of the hind tarsus. Siphunculi are swollen in the upper half.

30(33) Siphunculi are 2 or more times longer than the cauda.

31(32) Processus terminalis is $1.25-1.57$ times longer than base of 6th antennal segment. Cauda with 5-6 setae. On Artemisia sibirica, A. ponticae, A. sp. India, China

C. indica Verma, 1974

32(31) Processus terminalis is 1.5-1.8 times longer than base of 6th antennal segment. Cauda with 5 setae. On Artemisia absinthium. Europe, Russia (Western Siberia, on $C$. artemisiae), Pakistan, Kazakhstan C. angelicae (del Guercio, 1911)

33(30) Siphunculi are no more than 1.95 times longer than the cauda.

34(35) Siphunculi are 1.85-1.95 times longer than the cauda. On Artemisia vulgaris. Japan C. artemisicola Takahashi, 1965

35(34) Siphunculi are no more than 1.8 times longer than the cauda.

36(37) Antennae are 0.5 .70 .7 of body length. The 8th tergite with 4-6 setae. Cauda with 5 setae. On Chrysanthemum coronarium. All around the world

C. rufomaculata (Wilson, 1908)

37(36) Antennae are $0.48-0.50$ of body length. The 8th tergite with 4 setae. Cauda with 5-6 setae. On Artemisia campestris, A. scoparia, A. marschalliana. Northern Europe, Russia (European part), Ukraine, Pakistan, Kazakhstan, China, Korea, Japan

C. campestrella Ossiannilsson, 1959

38(1) Siphunculi are normally shorter than the cauda, if they are 1.0-1.2 of its length, then the dorsal setae on the 3-5th tergites of the abdomen exceed the diameter of the $3 \mathrm{rd}$ segment of the antennae at the base, and the siphunculi are no more than 1.2 times the length of ultimate rostral segment.

39(44) The ultimate rostral segment is 1.2-1.6 times longer than the second segment of the hind tarsus.

40(41) Siphunculi and cauda are brown. Siphunculi are $0.65-0.75$ of cauda length. On the 8th tergite of the abdomen no more than 6 setae. On Artemisia sp. Europe, Pakistan, Korea C. submissa Doncaster, 1961

41(40) Siphunculi, except for the apex, and the cauda are light. Siphunculi are $0.85-1.15$ of cauda length. On the 8 th tergite of the abdomen are 8 or more setae.

42(43) Antennae are five-segmented. The setae on the 8th tergite of the abdomen are fanshaped. Processus terminalis is $0.90-1.13$ of the base length of the last segment of the antennae. On Artemisia sp. Turkey, Pakistan, Uzbekistan, Mongolia

C. paradoxa Szelegiewicz, 1969 
43(42) Antennae are six-segmented. The setae on the 8th tergite of the abdomen are elongated and dull. Processus terminalis is 1.3-1.8 times longer than base of last antennal segment. On Artemisia (Seriphidium) spp. South Palearctic

C. heinzei (Börner, 1952)

44(39) The ultimate rostral segment is approximately equal to the length of the 2nd segment of the hind tarsus.

45(48) The setae on the 3-5th tergites of the abdomen are long, thin, at the end are forked or palette-knife form, 3 or more times the diameter of the 3rd antennal segment at the base.

46(47) Processus terminalis is 2.1-2.3 times longer than base of 6th antennal segment. Siphunculi are $0.75-0.80$ of cauda length. The ultimate rostral segment with 2 accessory setae. Green, cauda and siphunculi are light. On Achillea santolina, Artemisia monosperma. Israel, Iran, Afghanistan ................................. C. santolinae Hille Ris Lambers, 1948

47(46) Processus terminalis is 1.9-2.1 times longer than base of 6th antennal segment. Siphunculi are $0.62-0.75$ of cauda length. The ultimate rostral segment with 6 accessory setae. Green, cauda and siphunculi are brown. On Artemisia santolina, A. taurica, A. tomentella, A. lanulosa. Ukraine (Crimea), Kazakhstan (west), Afghanistan

C. taurica (Mamontova-Solukha, 1963)

$48(45)$ The setae on the $3-5$ th tergites of the abdomen are no more than 1.5 times the diameter of the 3 rd antennal segment at the base.

49(52) Siphunculi and cauda are light.

50(51) The setae on the dorsal side of the body are rod-shaped. On Artemisia abrotani. Sweden, Germany, Canada (introduced)

C. abrotani (Koch, 1854)

51(50) The setae on the dorsal side of the body are capitate and palette-knife form. On Artemisia procera. Ukraine, Kazakhstan ..... C. brevisiphon Bozhko et Shaposhnikov, 1964

52(49) Siphunculi and cauda are dark brown. On Artemisia campestris, A. marschalliana, A. scoparia. Western Europe, Russia (European part), Ukraine, Pakistan, Kazakhstan ..........

C. campestris Börner, 1939

\section{REFERENCES}

Blackman, R.L. \& Eastop, V.F. 2006. Aphids on the World's Herbaceous Plants and Shrubs. Vol. 1-2. Wiley, Chichester. 1439 pp.

Börner, C. 1939. Kleine Mitteilungen über Blattläuse. Überreicht vom Verfasser: 1-4.

Börner, C. 1940. Neue Blattläuse aus Mitteleuropa. Zweigstelle der Biologischen Reichsanstalt: $1-4$.

Börner, C. 1952. Europa Centralis Aphides die Blattlause Mitteleuropas. Mitteilungen des Thüringischen Botanischen Gesellschaft. Beiheft 3. Weimar. 488 pp.

Bozhko, M.P. 1953. New aphids species (Aphididae) from the steppe zone of East Ukraine. Entomologicheskoye Obozreniye. 33: 291-296. [In Russian]

Bozhko, M.P. 1976. New and little known species (Homoptera, Aphidoidea) of the south of European part of USSR. Entomologicheskoye Obozreniye, 55(4): 863-874. [In Russian]

Favret, C. 2019. SF Aphid: Aphid Species File (version 5/0, Jun 2019). Available at: http:/aphid.species.file.org. ISSN 2405-8858.

Heie, O.E. 1991. The Aphidoidea (Hemiptera) of Fennoscandia and Denmark. IV. Family Aphididae: Part 1 of tribe Macrosiphini of subfamily Aphidinae. Fauna Entomologica Scandinavica, 25: 1-188.

Hille Ris Lambers, D. 1948. On palestine aphids, with descriptions of new subgenera and new species (Homoptera, Aphididae). Transactions of the Royal Entomological Society of London, 99(6): 269-289. 
Ivanovskaja, O.I. 1977. Aphids of West Siberia. Vol. 1-2. Nauka, Novosibirsk. 597 pp. [In Russian]

Kadyrbekov, R.Kh. 2004. New species of Coloradoa Wil. genus (Homoptera: Aphididae, Macrosiphini). Selevinia, 12: 7-12.

Mamontova-Solukha, V.O. 1963. New data about Aphids fauna (Homoptera, Aphidoidea) of Ukraine. Trudy Instituta Zoologii AN Ukrainskoi SSR, 19: 11-40. [In Ukrainian]

Nevsky, V.P. 1929. Aphids of Middle Asia. Tashkent. 424 pp. [In Russian]

Ossiannilsson, F. 1959. Swedish Aphids. I. Description of some apparently undescribed forms. Annaler, 25: 1-46.

Remaudiere, G. \& Leclant, F. 1969. Deux Coloradoa nouveaux vivant sur Santolina en Europe occidentale (Homoptera, Aphididae). Annales de la Société entomologique de France, 5(3): 657-668.

Remaudiere, G. \& Remaudiere, M. 1997. Catalogue des Aphididae du monde. INRA, Paris. $473 \mathrm{pp}$.

Szelegiewicz, H. 1969. Neue Blattlause (Homoptera, Aphididae) aus der Mongolei. Annales zoologici, Warszawa, 27: 169-194.

Szelegiewicz, H. 1981. The aphids (Homoptera, Aphidoidea) of the Hortobagy. P. 77-87. In: Fauna of the Hortobagy National Park: Akadémiai Kiadó. Hungary. Budapest.

Shaposhnikov, G.H. 1964. Suborder Aphidinea - Aphids. P. 489-616. In: Bey-Bienko, G.Ja. (Ed.). Key to the insects of European part of USSR. Vol. 1. Nauka, Moscow - Leningrad. $935 \mathrm{pp}$.

Takahashi, R. 1965. Some new and little known Aphididae from Japan. Insecta Matsumurana, 28(1): 19-61.

Zhang, G. \& Zhong, T. 1980. New species and subspecies of Chinese Macrosiphinae (I) (Homoptera, Aphididae. Entomotaxonomia, 2(1): 53-63. [In Chinese]

Verma, K.D. 1974. A new species and two new undescribed morphs of aphids (Homoptera, Aphididae) from north-west India. Indian Journal of Entomology, 36(3): 200-202.

(C) Far Eastern entomologist (Far East. entomol.) Journal published since October 1994. Editor-in-Chief: S.Yu. Storozhenko

Editorial Board: A.S. Lelej, S.A. Belokobylskij, M.G. Ponomarenko, E.A. Beljaev, V.A. Mutin, E.A. Makarchenko, A.V. Gorochov, T.M. Tiunova, M.Yu. Proshchalykin, S.A. Shabalin

Address: Federal Scientific Center of the East Asia Terrestrial Biodiversity (former Institute of Biology and Soil Science), Far East Branch of the Russian Academy of Sciences, 690022, Vladivostok-22, Russia.

E-mail: storozhenko@biosoil.ru web-site: http://www.biosoil.ru/fee 